DOI: 10.31392/NPU-nc.series14.2019.27.10

УДК378.011.3-051:78

Калішук О. Д.

\title{
Характеристика структури виконавської мобільності майбутніх педагогів-музикантів
}

\begin{abstract}
Досліджується феномен виконавської мобільності педагога-музиканта за допомогою формалізації ії змістової структурної характеристики шляхом виявлення та впорядкування окремих елементів, які об'єднані в чотири компоненти: інформаційно-потребовий, операційно-технологічний, емоційно-оцінний та творчо-комунікативний. Проведений аналіз уможливлює наукове пояснення сутності, специфіки та значення кожного з складових елементів досліджуваної структурної характеристики. Розглянуті теоретичні основи формування виконавської мобільності майбутніх педагогів-музикантів є базою для подальшої теоретичної розробки та методичного обгрунтування шляхів педагогічного впливу на студентів 3 метою формування їх виконавської мобільності в процесі фортепіанної підготовки.

Ключові слова: виконавська мобільність; структурна характеристика; елементи та компоненти.
\end{abstract}

Актуальність дослідження. Сучасні вимоги до підготовки конкурентоздатного педагогамузиканта в загальноосвітній школі передбачають наявність не тільки високого рівня професійної компетентності та майстерності у музично-педагогічній діяльності, а й спроможність забезпечити динамізм протікання творчого процесу музичного виконання , здатність до його адаптивності щодо змін умов професійної діяльності, тобто володіння різноманітними способами та уміннями, які забезпечують виконавську мобільність фахівця. Виконавською мобільністю педагога-музиканта будемо вважати інтегративний динамічний показник, що характеризує його здатність до варіативних змін в процесі виконавської діяльності з метою найбільш вдалого вирішення ситуативних виконавських проблем. Поняття виконавської мобільності розглядалось різними вченими (Л.Горюнова, Б.Ггошев, Ю.Калиновський, Т.Луданова, О.Яненко та ін.), які заклали теоретичне підгрунтя для досліджування цього феномену. Для виявлення та впорядкування елементів, які формують виконавську мобільність, необхідно формалізувати іiі структуру, яка, маючи чітку оформленість, буде основою для подальшого аналізу означеного феномену.

У філософії поняття “структура” тлумачать як засіб закономірного зв’язку між складовими предметів і явищ природи і суспільства, мислення і пізнання; як сукупність істотних зав'язків виділених частин цілого, що забезпечує його єдність [5,c.634].

Звідси можна зробити висновок,що структура виконавської мобільності вчителя музики полягає у єдності окремих складових, детальний опис яких буде викладений в даній статті. Найбільш вдале розкриття структурно-змістової сутності виконавської мобільності студентапіаніста буде здійснено з позиції особистісного підходу який, в свою чергу, проявляється у відповідному конструюванні та реалізації навчального процесу.

Виклад основного матеріалу. 3 метою формалізації структури виконавської мобільності майбутніх педагогів-музикантів визначимо її структурні складові, в основу яких покладено принцип цілісного поєднання компонентів. Будемо виокремлювати ключові слова, які охоплюють поняття «мобільність» як систему. Отже розглянемо послідовно компоненти, 3 яких утворюється структура виконавської мобільності.

Інформаційно-потребовий компонент охоплює музично-теоретичні, музично-історичні та спеціальні знання, а також відображає готовність до оволодіння виконавською діяльністю та обсяг іiі інформаційного забезпечення.

Формування системи музично-теоретичних знань складає основу розвитку музичного мислення музиканта-інструменталіста. Ці знання необхідні для усвідомлення закономірностей музичного мистецтва, розуміння музичної форми, що буде сприяти вихованню активного музичного слуху та музичної пам“яті. Загалом музично-теоретичні знання дозволяють розглядати музичне мистецтво як цілісну художню форму.

Музично-історичні знання музиканта-інструменталіста щодо особливостей музики різних 
історичних епох, музичних стилів, творчості композиторів сучасності та минулого дозволяють йому успішно здійснювати жанрово-стильову атрибуцію, проявляти самостійність в аналізі елементів музичної мови, iї виразних якостей в процесі сприйняття творів. Створення повної та цілісної уявної картини щодо історичного розвитку музики передбачає два аспекти: охоплення фактичного історичного матеріалу та його теоретичне осмислення. Осягнення майбутніми вчителями музики закономірностей музично-історичного процесу дасть їм змогу сформувати своє історико- стильове мислення, що забезпечить глибину вивчення локальних музично-стильових питань та широту охоплення загальних історико-культурних проблем.Все вищезазначене допоможе здійснити в процесі виконавської діяльності швидку актуалізацію потрібної інформації та забезпечить стилевідповідне та жанрово переконливе виконання.

Окрім музично-теоретичних та музично-історичних знань суттєву роль у змісті інформаційно- потребового компоненту відіграють спеціальні знання. До таких знань відносяться: інформація щодо особливостей та прийомів звукоутворення на інструменті, знання динамічних можливостей свого інструмента, його тембральних особливостей, ролі педалізації; знання виразних можливостей штрихів та агогіки, обізнаність щодо репертуару тощо.

До спеціальних знань, окрім розуміння специфіки технологічних процесів, входять також знання, які можна віднести до особливостей музичного сприйняття різновікової аудиторії, поінформованість щодо можливостей регуляції психофізичного стану виконавця, обізнаність у сфері взаємодії музичних партнерів в ансамблевому музикуванні тощо.

Важливо розуміти,що досягнення виконавської майстерності можливе через оволодіння відповідними уміннями та навичками, а саме: опанування психофізичним станом виконавця залежить від якості певних психічних процесів, таких як пам'ять, концентрація уваги в момент виконання, особливості психічних реакцій, здатність до самоконтролю та саморегуляції, спроможність віднайти відповідну емоційну забарвленість твору.

Операційно-технологічний компонент включає в себе інструментально-виконавські уміння та навички, концертмейстерські уміння, здатність концентрувати увагу та мати стресостійкість у процесі виконання.

Оволодіння інструментально-виконавськими уміннями $\epsilon$ передумовою здатності до ефективної реалізації музикантом своїх професійних можливостей. Аналіз досліджень музикантів-педагогів дозволив сформувати перелік чинників, які інтегрально характеризують ефективність оволодіння інструментально-виконавськими уміннями: музичні здібності, серед яких найважливішим є музичний слух; анатомічні властивості музиканта; його особистісні якості, методи навчання музики та технологія індивідуальної праці. Успішність набуття такого уміння зумовлена властивостями нейродинаміки, загальномузичною обдарованістю (музикальність), рівнем музично-виконавською підготовки. Зокрема Т. Завадська вказує, що нейродинамічні характеристики людини визначають темп іiі реакції, швидкість набуття навичок або способів дій, обумовлюють професійну придатність людини до обраної праці, визначають темперамент особливості та характер особистості, що стає основою індивідуального стилю людини як фінального етапу становлення професіонала [2, с. 63 ].

Крім того, музиканту-інструменталісту дуже важливо володіти навичками ансамблевого виконавства : побудовою в ансамблі загального виконавського плану, виконання узгоджених дій з партнерами, досягнення з ними єдиного темпу, артикуляції, фразування , нюансуванням i, як результат, досягнення звукового та динамічного балансу.

Концертмейстерська діяльність вимагає комплексного використання певних професійних умінь, головним та засадничим з них $є$ вільне, технічне досконале володіння інструментом; ритмічність; динамічне різноманіття; вміння легко оволодівати нотним текстом та адаптуватись до стилю твору, що виконується з музичним партнером. Концертмейстеру необхідно розвивати внутрішній слух, музичну пам'ять, уміння читати «з листа», транспонувати, підбирати на слух. 
Крім того, концертмейстер повинен мати навички обробки творів, їх перекладення для різних складів виконавців. Вищий рівень професіоналізму концертмейстера - вміння передбачити та аналізувати зміст музичного твору з деяким випередженням. Коло його уваги широке, складне та об'ємне. Концертмейстер повинен не тільки слухати своє виконання в даний момент часу, але і чути та контролювати, що робить в кожний момент виконання соліст. Многопрофільність концертмейстерської діяльності проявляє себе в багатоплановості видів та складів виконавських колективів, безпосередньо з якими працює концертмейстер. Специфіка кожного з колективів передбачає варіативність дій музиканта - концертмейстера, а звідси наявність виконавської мобільності.

Концертмейстерська увага для музиканта важлива для того щоб вміти швидко зреагувати на зміни в діяльності, передбачити можливі ускладнення, віднайти відповідні рішення в разі якщо в цьому $\epsilon$ потреба, все це уможливлюють формування мобільності в аспекті іiі операційно-технологічного компоненту. Отже, суттєвим елементом операційно-технологічної складової виконавської мобільності виступає здатність до концентрації уваги та стресостійкість виконавця.

Увага має ряд властивостей: стійкість, зосередженість, переключення, розподіл, які проявляються у різних музикантів по різному та пов'язані з індивідуальними особливостями їх нервової системи, здібностями, досвідом роботи, тренованістю. Концентрація уваги потрібна, щоб музикант на сцені зміг зорієнтуватися в акустичних особливостях залу, пристосуватися до специфіки звучання інструменту та налаштувати до нього власний виконавський апарат.

М.Жижина вважає, що «... процес концентрації уваги підпорядкований творчій задачі, який в свою чергу сприяе стійкому самоконтролю музиканта за виконанням твору. Динаміка уваги певною мірою визначена змістом твору та задумом композитора» [1, с. 48].

Стрес $є$ системою реакцій організму у відповідь на загрозу реальну чи уявну, що негативно впливає на здатність особистості успішно керувати своїм психічним станом. Стресостійкість - це готовність до екстремальних дій в екстремальних ситуаціях [4, с.42]. Вона стає можливою завдяки професійному досвіду музиканта та його адекватної оцінки ситуації. Стресостійкість $€$ найважливішим компонентом надійності музикантаінструменталіста. В контексті стресостійкості музиканта-піаніста можна виявити чинники, які трапляються в його діяльності : подолання синдрому сценічного хвилювання, бути адекватно стійким та впевненим щодо свого виступу, тобто брати відповідальність за своє виконання, долати такі прояви, як страх забути текст, страх публіки. Існує два аспекти самовідчуття музиканта перед сценою - негативне налаштування себе, що призводить до неможливості проявити свій творчий задум на сцені, і позитивний настрій, який допомагає мобілізуватися та донести блискуче до публіки свій творчий задум, тобто бути стресостійким у сценічних виступах. Операційно-технологічний компонент виконавської мобільності складається 3 елементів, які характеризують інструментально-виконавське уміння, в тому числі ансамблеве виконання та концертмейстерську діяльність, які в значній мірі залежать від концентрації уваги та стресостійкості виконавця.

Емоційно-оцінювальний компонент характеризується здатністю майбутнього педагогамузиканта до осягнення емоційно-образного змісту твору та емоційного резонування з ним, усвідомлення можливостей саморегуляції виконавської діяльності. За допомогою емоцій, які виражає музика, музикант-інструменталіст може передавати образний зміст твору. Музичний твір має наступні характеристики: весела, сумна, ніжна, спокійна, урочиста, мужня, схвильована, серйозна, таємнича, страшна, тощо. При цьому кожна з цих характеристик має свої відтінки: весела музика може бути урочисто-святковою і жартівливо-безтурботною, танцювальною,урочиста музика може бути радісною, а може мати урочисту скорботу і т.д.

Осягнення емоційно-образного змісту твору здійснюється завдяки реалізації двох задач. Перша 3 них - інтелектуальна, яка полягає у тому, щоб зрозуміти та усвідомити задум композитора. Втілення цієї задачі повинно трансформуватися в сферу наступної емоційної 
задачі, яка характеризується емоційними переживаннями авторського задуму. Музикантінструменталіст таким чином реалізує своє емоційне ставлення до певного музичного твору.

Емоційне резонування - це здатність особистості відгукуватись на різні емоційні стани партнерів [6. с. 142]. Т. Ю. Строгаль вважає, що емоційний резонанс між людьми зумовлює додавання їхньої енергії, яка закладена в емоціях, а також стимулює додатковий психологічний ефект взаємодії - синергізм. [4. с. 113 ]. Синергізм під час виконавської діяльності музикантів сприяє об'єднанню їх енергетичних потенціалів і підвищенню ефективності спільної виконавської діяльності.

Синергізм можливий в ситуації, коли емоційна сприйнятливість партнерів у виконавській діяльності має форму емоційної чуйності, що заражає один одного своїми почуттями та переживанням.

Складовими компонентами саморегуляції $\epsilon$ психічна готовність до самооцінки, самоконтролю, самокорекції. Особливу роль для музиканта-інструменталіста відіграє емоційний самоконтроль як фактор його емоційної стійкості. Такий контроль дозволяє виявляти відхилення у порівнянні зі звичайним станом в характері їх протікання та дає можливість запустити механізм корекції,спрямований на стабілізацію емоційного реагування. Це означає, що майбутній педагог-музикант зможе вірно оцінити як перебіг виконавської діяльності, так і іiі результат, а також віднайти надійні засоби управління власним емоційним станом.

Творчо-комунікативний компонент включає здатність музиканта-інструменталіста до інтерпретації та варіантності його виконавської діяльності, характеризує комунікативну ініціативність та швидкість адаптації до соціально-культурних умов музичного виконавства.

У процесі виконавської діяльності музикантом-інструменталістом авторського нотного тексту він вносить в нього індивідуальні перетворення, які зумовлені індивідуальністю виконавської інтерпретації музиканта. Залежно від манери інтонування виконавця,визначається його творча індивідуальність, ступень чуйності до сприйняття музики, можливе різне розкриття ії образного змісту та емоційного ладу.

Музично-комунікативна ініціативність характеризується відкритістю творчих контактів, яка обумовлює готовність до взаємодії з партнерами-музикантами та слухачами, бажання спільно займатись виконавською діяльністю. Вона передбачає взаємне прагнення розуміти, співпереживати та приймати думку партнера-музиканта, раціонально реагувати на ситуації,пов'язані 3 вирішенням ситуативних проблем. При цьому важлива первинна ініціатива та наполегливість музиканта у встановленні музично-комунікативних зав'язків 3 партнерами та слухачами.

Адаптацію музиканта будемо розглядати як його здатність пристосувати свої знання, уміння та емоційні компетенції до умов діяльності в соціально-культурній сфері, що стрімко змінюються. Така здатність дозволяє музиканту-інструменталісту швидше пристосовуватись до швидкоплинних обставин та ситуацій виконавської діяльності та ініціативніше налагоджувати музично-комунікативні зв’язки з партнерами - музикантами.

Швидкість соціально-творчої адаптації майбутнього педагога-музиканта - це придбання професійного досвіду, швидкість входження у професійне музичне середовище, оволодіння прийомами, стандартами та цінностями цього середовища. Необхідною умовою швидкої адаптації є актуалізація теоретичних знань про попередній досвід, методи та принципи творчої діяльності музикантів-інструменталістів, які $є$ беззаперечними професійними авторитетами в цій сфері мистецтва, її еталоном.

Володіння навичками соціокультурної комунікації дозволяє майбутньому вчителю музики швидче та 3 мінімальними психофізичними витратами включитись в професійний процес взаємодії з можливими партнерами-музикантами щодо спільній виконавській діяльності та різними категоріями слухачачів, досягати злагодженості виконавських дій, створювати позитивний емоційний клімат в творчому колективі, що в кінцевому трезультаті, повинно 
додати динамізму та ефективністі процесу виконавської діяльності, а значить зробити ії більш мобільною.

Висновки. Отже, проведений змістовно-структурний аналіз виконавської мобільності майбутнього вчителя музики дозволив послідовно виявити та впорядкувати іiі окремі елементи, що були об’єднані в чотири компоненти: інформаційно-потребовий, операційнотехнологічний, емоційно-оцінювальний та творчо-комунікативний. Такий підхід уможливив наукове пояснення іiї сутності, специфіки та значення кожного з іiї складових елементів. Але в практичній діяльності педагога-музиканта усі вищезазначені компоненти синтезовані, створюють єдину систему фахових знань та умінь, спрямованих на цілісне формування досліджуваного феномену виконавської мобільності у майбутніх вчителів музики вищих навчально-педагогічних закладів освіти.

\section{Література}

1. Жижина М.В. Психолого-педагогические факторы и формирование исполнительского внимания музыканта. - Издательство Саратовского университета. - Саратов, 2002. - 138 с.

2. Завадська T.М. Нейродинамічні основи психофізичного стану студентів різного професійного напрямку навчання. Актуальні проблеми психології. Том V. Вип.12., с.63-70.

3. Казаченко А.П. Психоустойчивость человека в экстремальных условиях деятельности. Диссертация на соискание ученой степени канд. психол. Наук. 19.00.01. - Л. 1976, - 187 с.

4. Строгаль Т.Ю. Формування емоційно-естетичного досвіду підлітків на уроках музики: Автореф. Дис. канд. пед. наук 13.00.02. Київ. 2018.

5. Філософський енциклопедичний словник. В.І.Шинкарук ( голова редколегії) та ін. - Київ : Абрис, 2002. - 742c.

6. Mead G.H. Mind, Selfand Society / G.H.Meal, - Chicago. University of Chicago Press, 1963. - 623 p.

\section{Про автора:}

Калішук Олександра Дмитрівна, провідний концертмейстер кафедри теорії та методики постановки голосу факультету мистецтв імені Анатолія Авдієвського, Національний педагогічний університет імені М.П. Драгоманова (Київ, Україна); ORCID: 0000-0002-0120-7834, ale.1983@ukr.net

\section{Characterization of the structure of performing mobility of future music-teachers}

Kalishuk O. D.

The article considers the phenomenon of executive mobility of a music teacher is investigated by formalizing its meaningful structural characteristics, by identifying and organizing individual elements, which are combined into four components: information-required, operational-technological, emotionalevaluative and creative-communicative.

In the basis of the formation of the system by musical-theoretical knowledge is the basis for the development of musical thinking of the instrumentalist musician. This knowledge is necessary for the understanding of the laws of musical art, understanding of the musical form, which will facilitate the cultivation of active musical hearing and musical memory. In general, music-theoretical knowledge allows one to regard musical art as an integral artistic form. In addition to that very important for the teacher musician to have the skills of ensemble performance: building in the ensemble of a general performance plan, achieving a scientific and dynamic balance.

The information-required component forms the basis for the development of musical thinking, contributes to the understanding of the laws of the musical-historical process, informs about the peculiarities of technological processes of performance, regulation of the psychophysical state of the performer. The operational and technological component envisages the use of future music teacher of his professional abilities, characterized by his instrumental and performing skills, including in ensemble and concertmaster activity.

This emotional-evaluative component determines the need to understand, understand and provide emotional experience of the composer's author's intention, provides the student-instrumentalist's ability to respond to different emotional states of the partners, assesses and corrects the course of the performing activity, making conscious self-regulation in the creative direction.

The creative and communicative component makes it possible for the future music teacher to make individual transformations in the author's text, characterizing the openness of contacts that determine the 
willingness to interact with music part and listeners, ensures the speed of its entry into the professional environment, gaining professional experience.

So, the conducted analysis provides a scientific explanation of the essence, specificity and significance of each of the constituent elements of the studied structural characteristics.

Keywords: executive mobility; structural characteristics; elements and components of structure.

\section{References}

1. Zhizhina M. Psychological-pedagogical factors and formation of the musician's performing attention. Publishing House of Saratov Universit. - Saratov, 2002.- 138 p.

2. Zavadska T. Neurodynamic bases of psychophysical condition of students of different professional direction of study. Actual problems of psychology. Vol. V. Vol. 12, p.63-70.

3. Kazachenko A. Psycho-stability of a person in extreme conditions of activity. Thesis for a Candidate of Science Degree. Psych. Science. 19.00.01. - L. 1976, 187 p.

4. Strogal T. Formation of emotional and aesthetic experience of teenagers in music lessons: Abstract. Dis. Cand. ped. Sciences 13.00.02. Kiev. 2018

5. Philosophical Encyclopedic Dictionary. V.Shynkaruk (the chairman of the editorial board) and others. - Kiev: Abris, 2002. - P.611- 742s.

6. Mead G.H. Mind, SelfandSociety / G.H.Meal /. Chicago, University of Chicago Press, 1963. 623 p.

About the author:

Kalishuk Oleksandra Dmitriivna, leading Concertmaster at the Department of Theory and Methods of Voice Production, Faculty of Arts named after Anatolii Avdiievskyi, National Pedagogical Dragomanov University (Kyiv, Ukraine); ORCID: 0000-0002-0120-7834, ale.1983@ukr.net 